\title{
On wind power integration into electrical power system: Spain vs. Denmark
}

\author{
R. Villafáfila ${ }^{1}$, A. Sumper ${ }^{1}$, A. Suwannarat ${ }^{2}$, B. Bak-Jensen ${ }^{2}$, R. Ramírez ${ }^{1}$, O. Gomis ${ }^{1}$, A. Sudrià ${ }^{1}$ \\ ${ }^{1}$ Centre of Technological Innovation in Static Converters and Drives (CITCEA) \\ Politechnical University of Catalonia (UPC) \\ E.T.S.E.I.B., Av. Diagonal, 647 Planta 2, 08028 Barcelona (Spain) \\ Phone/Fax number: $+34934016727 /+34934017433$ \\ E-mail: roberto.villafafila@citcea.upc.edu,sumper@citcea.upc.edu, \\ ramirez@citcea.upc.edu,gomiz@citcea.upc.edu,sudria@citcea.upc,edu \\ ${ }^{2}$ Institute of Energy Technology (IET) \\ Aalborg University (AAU) \\ Pontoppidanstræde 101, 9220 Aalborg (Denmark) \\ Phone/Fax: +4596359240/+4598151411 \\ E-mail: aks@iet.aau.dk,bbj@iet.aau.dk
}

\begin{abstract}
Economic, social and environmental concerns demand higher efficiency and more sustainable electrical power systems. Then, power systems need to evolve from its traditional conception to future power systems. New nonconventional generators are distributed in power systems, most of them based on renewable resources, which have been developed and connected to the grid. Wind power is nowadays considered as one of this future renewable energy sources and it is more and more spread over the world. But there are a number of technical issues to be solved in order to accommodate these new units. Moreover, technical grid code requirements and regulations vary considerably from country to country. Denmark is the leader in wind power integration and development, and it is considered as a pattern to be followed. Wind power in Spain is also important. However, there are some facts between both countries that cause important differences. This paper points out some of them and suggests some strategies to be dealt with regarding wind power integration in Spain.
\end{abstract}

\section{Keywords}

Distributed Generation, Wind Power Integration, Grid Codes, Regulation, Power Quality

\section{Introduction}

Europe has an increasing concern of the dependence on foreign energy resources. The European Comission is aware of that within $20-30$ years, $70 \%$ of EU's energy needs will be imported, compared to $50 \%$ today [1]. These needs are mainly fossil fuels, which are the main cause of green-house gases. Moreover, fossil fuels will no longer be abundant and cheap, and [1] predict a $2 \%$ increase per year in EU primary energy consumption until 2020.

Therefore, the energy issue has become a priority in the EU agenda [2] and EU promotes a common energy policy with the following long-term goals: sustainable development, security of energy supply and the competitiveness in energy markets. These targets encourage the use of new technologies to reduce fossil fuel dependency and increase the use of domestic resources. Thus, there is an increasing demand for the integration of non-conventional generation units in the electrical power systems in order to reduce the economical dependence of fossil fuels and to contribute to a more sustainable and more efficient power system.

These new non-conventional technologies are wind turbines, photovoltaic systems, micro-hydro turbines, and combined heat and power (CHP) units. Most of them are based on renewable sources as wind, solar radiation, and water flow. Others are gas or biomass fuelled, like CHP plants. And lately there are an interest in researching other new non-conventional power sources like fuel cells, tide power and wave power, young technologies that are to be connected also in the future.

As renewable resources are not present everywhere, the renewable energy units are installed where the prime mover is. Then, this non-conventional generation units are mainly distributed in the power systems. So, they are associated to a distributed generation (DG) concept, although this should not be considered as a proper definition [3].

Renewable resources like for instance wind and PVsystems have natural variations, so they are not dispatchable and it is necessary to evolve to more active power systems to balance their stochastic power production in the power system in real time. Then, their integration into the power systems has not only a number of technical challenges, but also economic and regulatory ones to be able to meet with the targets of security of supply, in terms of reliability, availability and power quality [4].

According to [5], the current integration level of DG in EU is important. In some countries this DG supplies $40 \%$ of the electricity demand. This is the situation in Denmark, where they since the 80 's has promoted district centralized heating with CHP plants in every town and wind power. The DG capacity installed in Spain is also high, close to $25 \%$ of generation capacity. Other 
European countries have approximately 20\%, like Germany, the Netherlands and Portugal.

This means a shift in the traditional power systems operation and control, from a centralized to a decentralized system, which implies that Europe needs to develop future power systems which are able to accommodate increasing amounts of these DG technologies [6].

\section{Wind Power}

Nowadays, wind power is the most non-conventional generation technology spread over Europe, and it is increasing over the world [10]. Wind technology progress during almost the three last decades, has resulted in today's wind farms looking like power stations, in addition wind turbines are being modular and rapid to install. It is also considered that wind power should contribute to a cheaper and more stable and sustainable electricity supply in accordance with the economic, social and environmental demands for the 21 st century.

Within this time, the European countries have been developing and implementing effective regulatory and policy frameworks to renewable energy, so Europe is now the world leader in wind energy, with almost $70 \%$ of world wind power capacity installed in 2005 [10]. Germany with $18,4 \mathrm{GW}$, Spain with $10 \mathrm{GW}$ and Denmark with $3,1 \mathrm{GW}$ are the main contributors to this position. In the rest of the world, USA is the main actor in America, with $9,1 \mathrm{GW}$; and in Asia, India is the most important country with $4,4 \mathrm{GW}$ [10]. There are other countries around the world that have reached $1 \mathrm{GW}$, like Italy, United Kingdom, the Netherlands, China, Japan and Portugal.

However, wind power provides less than $3 \%$ of the European power needs [9], although in some particular countries it provides more than this. The current wind power production levels are $20 \%$ in Denmark, $8 \%$ in Spain, and 5,5\% in Germany [10], which means that the European targets of a wind power delivery of $12 \%$ by 2020 and in excess of $20 \%$ by 2030 [9] are not an utopia.

There are a number of issues about wind power integration which is also reflected in the technical grid code requirements and regulations which vary considerably from country to country. This paper wants to point out some of the different considerations on wind power integration according to the network and the operation and control, focusing the existing differences between the two countries with large scale power penetration in the final power production, Denmark and Spain.

\section{Wind power integration}

Wind power impact mainly depends on its penetration level, but depends also on the power system size, the mix of generation capacity, the degree of interconnections to other systems and load variations [5].
Set up of wind power define its control and operation. This set up is also influenced by other issues, as for example, wind resources and their location, and how the population is scattered in a country because it has influenced the power system development story.

Anyhow, wind power should not be analysed isolated from the other parts of the electrical power system. Its intermittent power production does not mean it is unreliable. Even demand is also variable. Therefore, the question is how to operate and control the power system to assure quality and availability of power with its inherent variability.

Penetration levels are sometimes limited because there is some reluctance to make changes in current power system procedures, more than technical issues. Nevertheless, Danish experience has shown that upgrading network operation to accommodate wind power and other not centralized generation does not represent a big problem with a proper regulatory framework [7, 9]. This shows again the need of evolving to future power systems that means a shift from centralized to decentralized power systems.

Spain is also introduced as an example of wind power experience in [9]. And the amount of DG units is significant, too [5]. There are, however, large differences between Danish and Spanish cases.

The first one, already quoted, is the installed capacity and production level. Both countries are on the top of wind power integration, but Spain has three times more wind turbines installed than Denmark. However, Denmark has almost three times higher wind power production. This difference has socio-geographical reasons. Denmark is ten times smaller than Spain and its population is also seven times less than in Spain. However, electricity consumption per capita $(\mathrm{kWh} /$ year) is almost the same in both countries [13], which mean that Spanish electricity consumption is seven times larger than the Danish. Moreover, Spanish people tend to live in cities while Danish people are spread over Denmark.

Following, a description of the power systems and current framework is done for both countries. Later, several issues about wind power integration in the electrical power systems will be described because control, operation and maintenance of transmission and distribution networks are totally different. In the same way, some economical aspects will be pointed out. Finally, some recommendations for the Spanish power system will be done according to Danish example.

\section{Power systems overview}

As it is quoted before, wind power integration partly depends on the power system. So it is necessary to describe first, the physical electrical power systems and their framework because these are the basis of most of the differences between wind power penetration in both countries. 


\section{Danish Power System}

\section{Transmission network}

Denmark's transmission system consists of 400, 150 and $132 \mathrm{kV}$ facilities. It is electrically divided into two areas, with different size and which are non-synchronous, which means there are managed differently:

- The western Denmark (Jutland and Funen) forms part of the continental European synchronous area UCTE. Here, the transmission grid is operated at 400 $\mathrm{kV}$ with a combination of ring connections and radial structure, and at $150 \mathrm{kV}$ as a parallel grid. It is connected to the UCTE synchronous area at the German border via $400 \mathrm{kV}, 220 \mathrm{kV}$ and $150 \mathrm{kV}$ AC lines (1200 import/800 export MW). The Western Danish system is also connected to the Nordel synchronous area, which includes Sweden, Norway and Finland, via HVDC links to Norway (1000 MW) and Sweden (720 MW) [11], which makes exchange of energy possible without it being synchronized.

- The eastern Denmark (Zealand) represents a part of another synchronous area, the Nordel. The Eastern transmission network is composed by a $400 \mathrm{kV}$ radial grid and a $132 \mathrm{kV}$ ring connected grid. It is connected to Sweden via AC lines (1700 import/1300 export $\mathrm{MW}$ ) and through a HVDC connection to Germany (600 MW) [11].

A HVDC link will connect these eastern and western grids by the year 2009 [7]. There are also some Danish islands that are not directly connected to these two main areas, but to another country, pointing out Bornholm being connected to Sweden at $60 \mathrm{kV}$.

Western Denmark total interconnection capacity is $2920 / 2530$ MW, which represents about $40 \%$ of the power capacity at this area and $75 \%$ of the maximum demand. In the case of Eastern area, total interconnection capacity is $2300 / 1900 \mathrm{MW}$, which is also around $40 \%$ of its generation and $85 \%$ of the maximum demand. The exchanged energy through the international connections in 2004 is shown in Table 1.

Denmark have had two transmission power system operators, one for each area, Eltra (Western) and Elkraft System (Eastern). However, since 2005 Energinet.dk is the only Danish transmission network operator, as well as for natural gas, and it is state owned. It is in charge for security of supply and market. Moreover, it owns the 400 $\mathrm{kV}$ facilities and the international connections, so it operates the grid and plans its expansion. However, 150 and $132 \mathrm{kV}$ installations belong to regional transmission operators that make them accessible to it $[7,11]$.

\section{Distribution network}

There are different distribution network voltage levels depending on the two quoted areas:

- $60 \mathrm{kV}, 20 \mathrm{kV}$ and $15 \mathrm{kV}$ are the most common in the Western part, although it is possible to find $10 \mathrm{kV}$.
- $132 \mathrm{kV}, 50 \mathrm{kV}$ and $30 \mathrm{kV}$ are used in the Eastern part.

Households and business normally have access to the electricity at 400 (3-phase) or 230 (single-phase) voltage. And industries are connected to the mains depending on their needs.

There are more than 100 distribution network companies who own and operate the grid. They are very different in size and number of customers. It is worth to mention that there is a significant amount of underground cables for voltage ratings below $20 \mathrm{kV}$.

\section{Generation mix}

Western Denmark has an installed power capacity of $7400 \mathrm{MW}$ and Eastern has $5350 \mathrm{MW}$. Then, the total capacity is $12750 \mathrm{MW}$. However, as the Western and Eastern power system are not connected yet, they have to be considered as two different power systems.

Denmark has around 6000 power generation units that can be classified in three types [12]:

- Centralized thermal power stations (West 3400 /East $4000 \mathrm{MW}$ ) that use mainly coal. They are located on 15 special sites and are operated for primary control.

- Combined Heat and Power (CHP) units (West $1600 /$ East $600 \mathrm{MW}$ ) that typically use natural gas, waste and biomass. They are operated decentralized and there are around 700 generators, including industrial and local plants.

- Wind turbines (West 2400/East $750 \mathrm{MW}$,) that are spread all over Denmark, decentralized operated and there are approximately 5000 units. Two off-shore facilities should be noted (Horns Rev $160 \mathrm{MW}$ and Nysted $158 \mathrm{MW}$ ) they are operated like traditional power plant and then, connected to the transmission grid.

Thus CHP units and wind turbines represent an important part of Denmark's installed power capacity, 54\% in Western area and $34 \%$ in the Eastern. This means around $40 \%$ for whole Denmark, as [5] also shows. This not centralized generation is mostly connected to the distribution network as figures from Western area show: $3900 \mathrm{MW}$ are connected $<100 \mathrm{kV}$ and $3500 \mathrm{MW}>100$ $\mathrm{kV}$. In the Eastern area, the situation turns round. The generation capacity $>100 \mathrm{kV}$ is $4000 \mathrm{MW}$ while $<100 \mathrm{kV}$ there is only $1350 \mathrm{MW}$. This is principally because there is a large urban area, composed by Copenhagen and its surroundings.

As the number of decentralized units is significant, this implies an on-going shift in Denmark from passive hierarchical network structure to an active network [6]. However, the power control centre can only organize the network over $100 \mathrm{kV}$ and the non-dispatchable generation units are beyond this centralized control.

This situation is remarkable on windy days. Centralized power plants have to adapt their power production 
according to CHP production and wind power generation. Those days, non-dispatchable units can afford the whole demand. The winter peak demand in Western Denmark is $3800 \mathrm{MW}$ and in summer, the minimum demand is 1200 MW. In Eastern Denmark, the winter peak demand is $2700 \mathrm{MW}$ and, the minimum demand is $1000 \mathrm{MW}$ in summer.

Anyway, large power plants are running for security of operation. Therefore, the excess of power production is exported through the interconnections. This is the reason why Denmark usually produces more electricity than it needs [12], so it uses its numerous interconnections to export the electricity and takes advantage of the decentralized electricity production.

\section{Future energy supply}

Denmark approved the present long-term energy strategy, called "Energy 21" plan, in the spring 1996.The Danish government has had other successful energy policies and has given up nuclear power. This plan supports the reduction of $\mathrm{CO} 2$-emission, promotes energy savings and the expanding of renewable energy utilization to substitute coal and keep the consumption of natural gas and oil almost the same. Thereby, the plan establish that the utilization of renewable energy in Denmark will have to rise from a level around $8 \%$ by that day to $12-14 \%$ by 2005 and $35 \%$ by the year 2030 . As quoted data show, Western Denmark has exceeded its target for 2005 defined in the "Energy 21" plan in $1500 \mathrm{MW}$.

The current targets have been overcome by use of CHP's and wind power generation around 40\% [5]. Moreover, Denmark holds the world record of electricity consumption generated by wind power, around $20 \%$ [10]. It is the core of global wind power development because the creation of a cluster around wind power where manufacturers, suppliers, research and educational institutions combine knowledge and expertise to innovate and advance in wind technology. By way of illustration, approximately half of the installed $40.000 \mathrm{MW}$ globally are turbines produced by Danish manufacturers.

\section{Spanish Power System}

\section{Transmission Network}

The Spanish network has two different kinds of power systems mainly because of geographical reasons:

- The peninsula is a bulk power system that forms part of the UCTE. The transmission system is composed by a meshed network of 400 and $220 \mathrm{kV}$ facilities. It is connected to the UCTE at the France border via 400 and $220 \mathrm{kV}$ AC lines (1400 import/300 export MW). The Spanish system allows that Portugal also forms part of UCTE with connections at 400 and 220 $\mathrm{kV}$ (1300 import/1600 export MW). Moreover, Spain is also connected to Morocco through a submarine $400 \mathrm{kV}$ AC line (400 MW), which permits the synchronous operation between the north of Africa and Europe. Some areas have a high voltage distribution network at 132 and $110 \mathrm{kV}$ that are partially meshed and are used as a kind of subtransmission network.

- The Balearic and Canary Islands are represented by weak power systems although with some differences between them.

Canary Islands have six small power systems; almost each of the Canary Islands represents one. There is only an electrical connection between two of the islands through a $66 \mathrm{kV}$ AC line. The interconnection between the rests is currently impossible due to the big sea depths. As well, only the two biggest islands have a small transmission network at $220 \mathrm{kV}$ and $66 \mathrm{kV}$ is used as transmission grid.

On the other hand, some of the Balearic Islands are connected via submarine 110 or $30 \mathrm{kV}$ AC lines and the whole main islands while be connected at $110 \mathrm{kV}$ by the year 2007. Moreover, the Balearic power system is planned to be connected by a High Voltage Direct Current (HVDC) link to the peninsula by the year 2009. The transmission network in the Balearic Islands is $220 \mathrm{kV}$, but 132 and $66 \mathrm{kV}$ is also considered a part of the transmission grid in this case and they are largely meshed.

Spain's total interconnection capacity is $3100 / 2300 \mathrm{MW}$, which represents about $4 \%$ of the power capacity at this area and $7 \%$ of the maximum demand. The exchanged energy through international connections in 2004 is shown in Table 1.

The Spanish transmission network operator is Red Eléctrica de España, REE, which is the only system operator. Then, it takes care of security of supply and market. It belongs only $20 \%$ to the state and it owns the 400 and $220 \mathrm{kV}$ facilities and the international connections. There are some 400 and $220 \mathrm{kV}$ facilities that do not belong to REE yet, but it manages the grid or is in the process to purchase them.

Red Eléctrica de España (REE) is responsible for secure and reliable operation of the power system, a well functioning energy market and for owning, operating and expanding the transmission infrastructure for electricity.

As the number of decentralized units is significant in Spain, REE has since June 2006 incorporated a specific power control centre for Special Regime generation to the current power control centre (CECOEL).in order to get a proper operation of distributed generation. This new control centre is called CECRE and is focused on the control of the non-dispatchable units, mainly CHP and wind power farms $<10 \mathrm{MW}$, each unit or a set of units with the same PCC. REE does not always have direct control so it gives the orders to the owners that they have to execute.

On the other hand, each of the isolated power system at the islands has its own power control centre although all of them are managed under REE supervision. 


\section{Distribution Network}

The Distribution network include from $132 \mathrm{kV}$ to $220 \mathrm{~V}$. As it has been quoted before, the high voltage level, 132 and 110 and $66 \mathrm{kV}$ are in part meshed and used as a subtransmission network, above all at the islands. Lower voltage networks are principally radial. However, the voltage ratings vary depending on the area because historical reasons. In the peninsula, the range is wide: 66 , $45,30,25,20$, and $11 \mathrm{kV}$ and so on down to $380,220 \mathrm{~V}$ for households and business. Industries connection depends on their needs.

Distribution is concentrated in five main utilities, although there are some smaller.

\section{Generation mix}

Generation supplied to the distribution networks, are concentrated in five main utilities. By way of illustration, $60 \%$ of wind power belongs to them. The Spanish generation power plants are divided in two big groups:

- Ordinary regime that includes the centralized power plants thermal units fuelled by natural gas (12224 MW), coal (11424 MW), uranium (7876 MW) or oil (6647 MW). Hydro power (16657 MW) is included in this group.

- Special regime (19.142 MW) that includes nonconventional generation and can be considered as a distributed generation. It comprises both non renewable (6645 MW) and renewable (12497 MW), like wind power $(9800 \mathrm{MW})$. Wind power is placed all around Spain but as wind farms.

The total power installed capacity in Balearic Islands is $1671 \mathrm{MW}$ shared in $660 \mathrm{MW}$ fuel/gas, $510 \mathrm{MW}$ carbon, $458 \mathrm{MW}$ natural gas and $43 \mathrm{MW}$ special regime, which only include $3 \mathrm{MW}$ wind power. In the case of Canary Islands, the total power installed is $2339 \mathrm{MW}$ shared in $1695 \mathrm{MW}$ fuel/gas, $452 \mathrm{MW}$ natural gas and $191 \mathrm{MW}$ special regime, which include $125 \mathrm{MW}$ wind power.

Special regime represents around $25 \%$ as [13] and [5] observe. Particularly, wind power represents $12 \%$ of total installed power capacity and $50 \%$ of special regime. The significant percentage of special regime has required the creation of a specific power control system for units over 10 MW to optimize the operation in combination with centralized power plants.

Ordinary generation satisfy $80 \%$ of the energy demand and special regime the rest. In particular, wind power supply $8 \%$ of total energy demand, as [10] also mentions. And these special regime generation units are mostly connected to the transmission or high-voltage distribution levels, that is, above $100 \mathrm{kV}$.

Spain has 73970 MW installed power capacity and the winter peak demand in Spain is 43400 MW. Nowadays, the peak demand in summer is also important, around $38500 \mathrm{MW}$. The minimum demand is $19000 \mathrm{MW}$. On windy days, wind power has reached up to $20 \%$ of power production but special regime can not provide all the energy needed.

\section{Future energy supply}

Spain agreed an energy plan in 1999, Plan de Fomento de las Energías Renovables 2000-2010, in order to motivate the use of renewable energy in electricity and heat production and for transportation by the year 2010 [15]. The targets are set up as $12 \%$ of total energy demand and $30 \%$ of electricity production to be covered by renewable energy. Particularly, for wind power is expected a power capacity over $20.000 \mathrm{MW}$, which is expected will represent $13,5 \%$ of total generated electricity.

At once, it guarantees the financial support and the regulation framework to achieve these goals. It also promotes some initiatives like a power control centre for wind power which is already working and the creation of synergies between manufacturers, operators, utilities universities and research institutions.

\begin{tabular}{|c|c|c|c|c|}
\hline \multirow{3}{*}{$\begin{array}{l}\text { Electricity } \\
\text { generated }\end{array}$} & \multicolumn{2}{|c|}{ Denmark } & \multicolumn{2}{|c|}{ Spain } \\
\hline & Wind & $\begin{array}{r}6.583 \mathrm{GWh} \\
(16,30 \%) \\
\end{array}$ & Wind & $\begin{array}{r}15.601 \mathrm{GWh} \\
(5,57 \%) \\
\end{array}$ \\
\hline & Total & $40.463 \mathrm{GWh}$ & Total & $279.953 \mathrm{GWh}$ \\
\hline \multirow{5}{*}{ Imports } & Country & $\begin{array}{l}\text { Energy } \\
\text { (GWh) }\end{array}$ & Country & $\begin{array}{l}\text { Energy } \\
\text { (GWh) }\end{array}$ \\
\hline & Sweden & 3.812 & France & 5.978 \\
\hline & Germany & 3.380 & Portugal & 2.112 \\
\hline & Norway & 1.481 & $\begin{array}{l}\text { Morocco } \\
\text { Andorra }\end{array}$ & 21 \\
\hline & Total & 8.673 & Total & 8.111 \\
\hline \multirow{5}{*}{ Exports } & Country & $\begin{array}{l}\text { Energy } \\
\text { (GWh) }\end{array}$ & Country & $\begin{array}{l}\text { Energy } \\
\text { (GWh) }\end{array}$ \\
\hline & Germany & 5.381 & Portugal & 8.531 \\
\hline & Norway & 3.781 & $\begin{array}{l}\text { Morocco } \\
\text { Andorra }\end{array}$ & 1.851 \\
\hline & Sweden & 2.383 & France & 757 \\
\hline & Total & 11.545 & Total & 11.139 \\
\hline \multirow{5}{*}{$\begin{array}{l}\text { Balance } \\
\text { exports- } \\
\text { imports }\end{array}$} & Country & $\begin{array}{l}\text { Energy } \\
\text { (GWh) }\end{array}$ & Country & $\begin{array}{l}\text { Energy } \\
\text { (GWh) }\end{array}$ \\
\hline & Norway & +2.300 & Portugal & +6.419 \\
\hline & Germany & +2.001 & $\begin{array}{l}\text { Morocco } \\
\text { Andorra }\end{array}$ & +1.830 \\
\hline & Sweden & -1.429 & France & -5.221 \\
\hline & Total & +2.872 & Total & +3.028 \\
\hline
\end{tabular}

Table 1 . Wind energy production and international exchanges Source: EUROSTAT (2004)

\section{Wind turbines grid connection}

Wind power integration presents important issues in terms of operational and extension modifications of power systems structure, connection requirements for wind turbines in order to maintain a stable and reliable supply, and its influence on the security of supply. Moreover, as wind power has grown faster than expected, and its penetration rates and technology development is going on, some grid codes are steadily being reformulated [9]. These facts have an increasing awareness since there is a change from wind turbines to wind power plants. 
Different power systems have different characteristics. Even transmission and distribution networks present some differences although they form part of the same power system. Wind power penetration level also influences the way of studies approach. Following some of these issues is pointed out.

\section{Grid code}

Wind power development has forced the networks operators to extend the grid codes for connecting generators with specific codes for wind turbines to assure that wind turbines integration do not affect the power system security. Different grid codes lead to different ways of testing wind turbines. Then, wind turbine manufacturers know the control requirements that their wind turbines have to meet for a proper security of supply, reliability and power quality.

Grid codes vary from country to country, since the power networks present different size, generation mix and operation procedures (robustness) and wind power penetration. Harmonization is on national level only, and then wind manufacturers have to adapt the wind turbines to each country, even within it because of different maximum interconnection capacity at the connection point.

Denmark and Spain have different grid codes, mainly due to their different power system and the wind power penetration.

Apart from forecasting wind power production, another important issue is voltage sags. Voltage sags can produce a significant loss of wind power simultaneously and then, system stability can be affected. As Danish and Spanish wind power penetration is high, ride-through capabilities are defined in the grid codes. Both grid codes say that wind turbines must remain connected during normal grid faults allowing the protection system to clear the fault. Nevertheless, the definitions of ride-through are different, as shown Figure 1 and Figure 2 for 3-phase short-circuits. Both Danish and Spanish grid codes differentiate between 3-phase, and 2 and single-phase short-circuits.

\section{Transmission network}

Wind power integration at transmission level must be focused in the global system control and at stability problems. Transmission network operators have to take care of the power balance between generation and demand, that is, security of supply.

For Denmark, wind turbines connected to transmission level must follow reference grid code TF 3.2.5 Wind turbines connected to grids with voltages above $100 \mathrm{kV}$ developed by Energinet in 2005 [9].

In the case of Spain, wind turbines connected to transmission level have to deal with both the operation procedures of grid code for transmission P.O. 12.1 Soluciones de acceso para la conexión de nuevas instalaciones a la red de transporte and FP.O. 12.2 Instalaciones conectadas a la red de transporte: requisitos mínimos de diseño, equipamiento funcionamiento $y$ seguridad y puesta en servicio that appear in MITYC in 2005 [9].

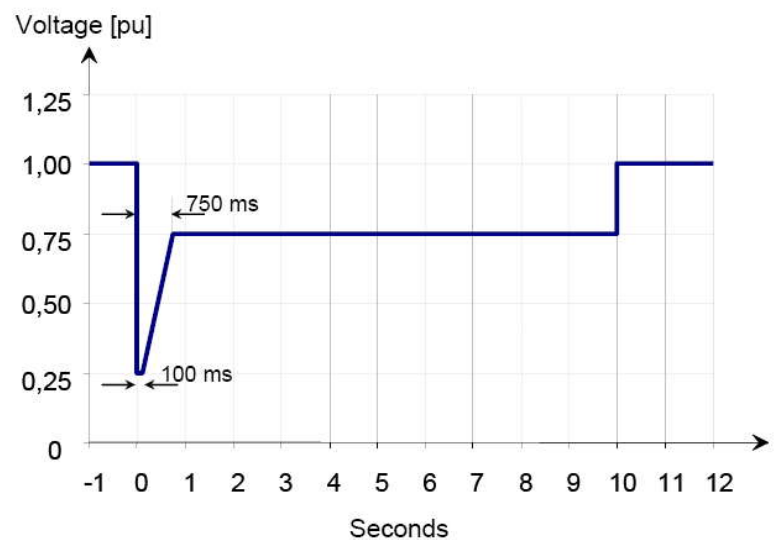

Figure 1. Ride-through capabilities at 3-phase short-circuit. Source: Wind turbines connected to grids with voltages below $100 \mathrm{kV}$. Technical regulations for the properties and the control of wind turbines. Danish grid code.

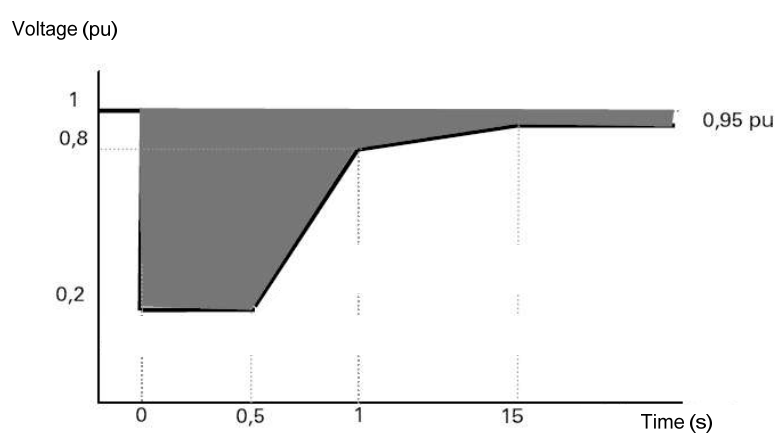

Figure 2. Ride-through capabilities at 3-phase short-circuit. Source: P.O. 12.3. Requisitos de respuesta frente a huecos de tensión de las instalaciones eólicas. Spanish grid code.

\section{Distribution network}

Wind power integration at distribution level focus on more local power quality problems. Distribution network operators take care of keeping the power quality, that means that the voltage seen by consumers is within acceptable limits.

For Denmark, wind turbines connected to distribution level must follow reference grid code TF 3.2.6 Wind turbines connected to grids with voltages below $100 \mathrm{kV}$ developed by Energinet in 2004 [9].

In the case of Spain, wind turbines connected to distribution level have to cope with the $R D$ 436/2004 Metodología para la actualización y sistematización del régimen jurídico y económico de la actividad de producción de energía eléctrica en régimen especial that appear in MITYC in 2004 [9].

As subsidies and premiums for wind power is for wind farms up to $50 \mathrm{MW}$, this is the larger size of wind farm facilities in Spain. Moreover, depending on the wind 
turbines, these wind farms can be made of 30 up to 70 wind turbines.

\section{Isolated networks}

Both Spanish archipelagos represent a weak power system. In such cases, wind power integration requires a different assessment because the operation of isolated power systems involves frequency stability as a main issue. A Danish wind power cluster is carrying out some research on this topic although for the western system.

The Balearic Islands do still not have a significant percentage of wind power. It is advisable to carry out some analysis before wind power is widespread. On the other hand, Canary Islands have a considerable amount of wind power.

Bornholm is an example of a Danish weak system with a power plant of $51 \mathrm{MW}$ and an important amount of wind power. However, it is connected to a bulk power system.

\section{Off-shore wind farms}

Wind over the sea is more steadily and powerfully than over land. Here, electricity can be generated with a greater degree of continuity. However, grids at the coast are usually weak and need a reinforcement to deal with off-shore wind farms.

Denmark has two off-shore wind farms. Onshore expansion is kept low in favour of offshore expansion because most of the best wind places are taken. Denmark is the first European country to construct commercialscale offshore wind farms. Therefore, Danish companies are leaders in offshore wind farms nowadays. Energi E2 (Nysted) is now active in offshore wind in Denmark, Sweden, the UK and Germany. And similarly, DongEnergy (Elsam), owner of Horns Rev, is willing for an extension to Horns Rev, and is also active in the UK.

Although in Spain there is not an off-shore farm, [14] considers subsidies for this technology. As for on-shore facilities, [14] distinguish between wind off-shore farms below and over $50 \mathrm{MW}$. Moreover, [15] remarks that there are some studies to develop off-shore wind farms but their implantation will be in a medium long-term.

\section{Planning and operation}

Wind is a natural resource with an inherit variation. Here, wind atlas is a useful tool to plan wind energy development. Moreover, it is necessary to develop wind forecast tools in order to assure the balance between energy production and consumption. Therefore, it requires an active power systems control. Then, conventional power plant systems have to be managed in different way. Expanding and reinforcing networks and international connections are also required as a solution for dealing with non-dispatchable sources of energy like wind power.

\section{Regulation}

\section{Denmark}

The Danish electricity market is a free market since 2003, according to an EU directive on full liberalisation of the electricity markets in 1999. It is an integral part of the Nordic electricity market, where trade is done via the power exchange Nord Pool. There will be further changes in the future to increase the integration of the Nordic market into the EU market. Energinet.dk is also working towards harmonised markets in the Eastern and Western areas because they have different regulation [energinet.dk website].

Denmark has given a wide range of incentives for renewables, and particularly, for wind energy. The subsidies depend on when the turbine has been connected and its age. For example, turbines connected prior to 2000 have a subsidy that ensures $60 \varnothing \mathrm{re} / \mathrm{kWh}$ with the market price until the full load allowance is used up, and thereafter $43 \varnothing r e / \mathrm{kWh}$ until it is 10 years old. A premium of $10 \varnothing \mathrm{re} / \mathrm{kWh}$ until the turbine is 20 years old is subsequently eligible. The premium is regulated in accordance with the market price, as the total of the two must not exceed 36øre/kWh. There are similar situations for turbines connected in the periods 2000-2002, 20032004 and from 2005, but the subsidy rates change. The cases of the off-shore wind farms are subsidised according to separate rules [12], although risks are covered effectively through government obligations. By way of illustration, the average spot price in 2005 was approximately $228 € / \mathrm{MWh}$.

Spain

The transition of the Spanish electricity market to a free market began at 1998 and finished in 2000, according to EU demands.

Spain has given a wide range of incentives for special regime generation units. Moreover, these generators have two choices to sell the energy if their power rating is less than $50 \mathrm{MW}$ : regulated price or pool price plus subsidies and premiums. For special regime units larger than 50 MW, these units only have energy market as an option. Independently from the option chosen and the power, these generation units can have complements for ancillary services.

Particularly, wind energy subsidies depend on the power and the age [14]. For example, on-shore wind power farms less than $5 \mathrm{MW}$ have a subsidy that ensures $90 \%$ of the market price during 15 years and $80 \%$ from that date. In addition, there are a premium of $40 \%$ regulated price and a bonus of $10 \%$ regulated price for sharing the pool. The situation is similar for wind farms larger than $5 \mathrm{MW}$, even for off-shore wind farms. By way of illustration, the average spot price in 2005 was $62,42 € / \mathrm{MWh}$. 


\section{Differences}

The main differences between Denmark and Spain are listed following:

- Distributed generation (CHP and wind power) can reach $100 \%$ of the Danish Western demand on load demand days. Moreover, wind power could satisfy $60 \%$ of maximum demand and supply the whole demand in low peak demand. However, special regimen can supply $40 \%$ of Spanish demand. And particularly, wind power has only reached $20 \%$ of the Spanish demand without important problems for the operation of the grid.

- There has been a pool price reduction with increased wind power production in Spain. This reduction is higher than the increase of balancing costs. In Denmark the market prices have not been reduced.

- International connections are used according to bilateral agreements and market in both cases. Then, some connections can export more import or viceversa. However, Danish interconnection capacity is around $40 \%$ of its generation in both systems. In Spain, it is around $4 \%$.

- New turbines have to meet ride-through requirement at faults is a usual practice in Denmark.

- Danish subsidies for wind energy depend on when the turbine has been connected and its age while they in Spain depends on the power and the age.

- The Danish energy strategy is based on a long-term plan while the Spanish is a short-term plan.

- The Spanish transmission grid operator manage only electrical power system while the Danish takes also care of gas.

\section{Conclusions}

The significant expansion of wind energy requires solving a series of technical and economic questions.

This paper has pointed out the features of Danish and Spanish experience regarding wind power and power systems. Denmark shows that it is possible to operate a network with a high wind power penetration, properly. A cluster where manufacturers, suppliers, research and educational institutions can meet and work together and a long-term energy plan are key points.

It should be mentioned that further analysis in each of the mentioned power systems is required and will be done. Determining the best technical and economical alternatives require an assessment of each situation. Denmark can be a point of reference to achieve some of the Spanish targets, not only regarding wind power but also for the development of future power systems.

\section{References}

[1] Comission of the European Comunities; "Towards a European strategy for the security of energy supply", GREEN PAPER COM(2000) 769 final, Brussels, 29/10/2000.

[2] Comission of the European Comunities; "A European Strategy for Sustainable, Competitive and Secure Energy", GREEN PAPER COM(2006) 105 final, Brussels, 8/3/2006.

[3] Ackermann, T.; Andersson, G.; Soder, L.: "Distributed generation: a definition," Electric Power Systems Research, 57, 2001, 195-204.

[4] Jenkins, N., Allan, R., Crossley, P., Kirschen, D., Strbac, G.: "Embedded Generation" IEE Press Publications, London, 2000.

[5] Ropenus, S.; Skytte, K., "Regulatory review and barriers for the electricity supply system for distributed generation in EU15," Future Power Systems, 2005 International Conference on , vol., no.pp. 6 pp.-, 16-18 Nov. 2005.

[6] European Comission; "European Technology Platform SmartGrids: Vision and Strategy for Europe's Electricity Networks of the Future", EUR-22040, Brussels 2006, ISBN 9279-01414-5.

[7] Eriksen, P.B.; Orths, A.G.; Akhmatov, V., "Integrating dispersed generation into the Danish power system - present situation and future prospects," Power Engineering Society General Meeting, 2006. IEEE, vol., no.pp. 7 pp.-, 18-22 June 2006.

[8] Eriksen, P.B.; Ackermann, T.; Abildgaard, H.; Smith, P.; Winter, W.; Rodriguez Garcia, J.M., "System operation with high wind penetration," Power and Energy Magazine, IEEE , vol.3, no.6pp. 65- 74, Nov.-Dec. 2005.

[9] EWEA report: "Large scale integration of wind energy in the European power supply: analysis, issues and recommendations", December 2005.

[10] GWEC report: "Global Wind Energy Outlook 2006", September 2006.

[11] Energinet.dk website: www. energinet.dk.

[12] Danish Energy Authority: "Energy in Denmark 2005".

[13] Red Eléctrica España (REE): "El sistema eléctrico español 2005", June 2006.

[14] REAL DECRETO 436/2004, de 12 de marzo.

[15] Ministerio de Industria, Turismo y Comercio de España: "Plan de Fomento de las Energías Renovables 2000-2010" 